\title{
Study of growth patterns of staphylococcus aureus in human blood and sheep
}

\begin{abstract}
This study aims to observe the growth pattern of Staphylococcus aureus on BAP media O, $\mathrm{AB}$ and sheep blood types as control. The purpose of this study was to test the feasibility of using human blood groups $\mathrm{O}$ and $\mathrm{AB}$ as important compounds in the manufacture of sheep BAP as a substitute for blood media. In this experiment, Blood Agar Plate (BAP) was tested using sheep blood as a substitute medium for human blood, which is used to identify and isolate the Staphylococcus aureus bacterium. The growth pattern of Staphylococcus aureus was observed macroscopically against colony morphology, the number of colonies, and the diameter of the hemolysis zone. Suspension of Staphylococcus aureus (ATCC 25923) using pure culture synchronized with McFarland's 0.5 Standard solutions. The depletion is then carried out 10. Suspension of bacteria that have undergone depletion is planted in BAP media $\mathrm{O}, \mathrm{AB}$ and sheep blood groups are filled in each of the 9 Petri dishes. The results of observations are known colony morphology, some colonies, and hemolysis zone diameters and statistical tests using the Kruskal Wallis test values obtained by Asymp. Sig of 0.352 for the number of colonies and the diameter of the hemolysis zone is greater than $\alpha(0.05)$, which means there is no significant difference between the growth patterns of Staphylococcus aureus on BAP media using human blood groups O, AB and sheep blood as BAP media control.
\end{abstract}

Keywords: bap, hemolysis, number of colonies, staphylococcus aureus
Volume 4 Issue 2 - 2020

\section{Eddiwan Kamaruddin}

Postgraduate Program in Environmental Sciences, Riau University, Indonesia

Correspondence: Eddiwan Kamaruddin, Postgraduate Program in Environmental Sciences, Riau University, Jl. Pattimura No. 9. Gobah, Pekanbaru, Riau, Indonesia, 28125,

Tel + 62-8I276-000-66, Fax + 62-76I-8569I,

Email eddiwan@lecturer.unri.ac.id

Received: April 14, 2020 | Published: April 29, 2020

\section{Introduction}

Microorganism growth media is a material consisting of a mixture of food substances (nutrients) needed by microorganisms for growth. Microorganisms utilize the nutrient media in the form of small molecules that are assembled to arrange cell components. Isolation of microorganisms to become pure culture can be done using growth media. ${ }^{1}$

Pugh et al., ${ }^{2}$ stated that the direction of sheep is an essential compound that is used for making blood agar media, and this media is a standard medium for the isolation of bacteria that can dissolve blood. Media so that blood contains the blood of mammals (generally sheep) that are not frozen by $5-10 \%$. The addition of blood aims to fertilize the seedling and to grow bacteria that are difficult to grow in an ordinary seed.

Besides this media can distinguish bacterial properties, the ability of bacteria to destroy erythrocytes. ${ }^{3}$ The blood of wool sheep (Wool Sheep) in a country like Indonesia is not easy to obtain, because wool sheep, are difficult to breed and cannot live and adapt to the tropical climate in Indonesia. Therefore, as an alternative human blood is used as an essential compound for making blood agar media. ${ }^{4}$

The human blood used is blood type $\mathrm{O}$ and $\mathrm{AB}$, because this blood type has differences in terms of the composition of the antigen. So it is necessary to conduct a feasibility test on the use of human blood groups $\mathrm{O}$ and $\mathrm{AB}$ as an essential compound in the manufacture of blood vessels, a substitute for sheep blood. ${ }^{5}$ Germination seed is useful for identifying disease-causing bacteria, treatment needs, if planted in pure culture can be used to study the properties of each type of bacteria and for industrial purposes can be used as the beginning of making antibiotics. ${ }^{6}$
Nutrients in seed media needed for bacterial growth are energy sources, carbon sources, nitrogen sources, $\mathrm{pH}$ 7.2-7.6, the right oxidation-reduction potential, sulfate salts, phosphates, and others. Generally, the material used for most microbiological media is agar, acid polysaccharides extracted from certain red algae. ${ }^{7}$ Lagier et al., ${ }^{8}$ states that Staphylococcus aureus is a spherical cell with a diameter of about $1 \mu \mathrm{m}$ and arranged in irregular groups. In liquid culture, there is also a single coccus, paired, tetrad and chain shaped. Young cocci are strong gram-positive, whereas, in older cultures, many cells become gram-negative. Staphylococcus aureus is immobile and does not form spores. By the influence of drugs such as penicillin, Staphylococcus aureus is lysed. ${ }^{9}$

Kim et al., ${ }^{10}$ states the optimal temperature for breeding Staphylococcus is $28-38^{\circ} \mathrm{C}$ or around $35^{\circ} \mathrm{C}$, but the best pigment formation is at room temperature $\left(20-25^{\circ} \mathrm{C}\right) .{ }^{11}$ If the bacteria are isolated from a patient, the optimal temperature needed is $37^{\circ} \mathrm{C}$. The optimal $\mathrm{pH}$ for the growth of Staphylococcus aureus is 7.4. In general, Staphylococcus can grow on mediums commonly used in bacteriological laboratories. ${ }^{12}$ for example:

\section{Nutrient agar plate}

The medium is important to know the existence of pigment formation and Staphylococcus aureus will form a golden-yellow pigment. Colonies that grow are round, 1-2 $\mathrm{mm}$ in diameter, convex with flat edges, shiny surfaces and soft consistency. ${ }^{13}$

\section{Blood agar media}

For optimum growth of Staphylococcus bacteria, 11 amino acids are needed. These bacteria also cannot grow on synthetic media that do not contain amino acids or proteins. In addition to amino acids 
or proteins, Staphylococcus also requires vitamins for example threonine, nicotinic acid, and biotin. In blood media, the need for protein is fulfilled by the addition of blood. ${ }^{14}$ Blood that is usually used is mammalian. Growing colonies appear large, medium, small, white to yellowish, convex, shiny surface and in a malignant strain usually provide clear zona hemolysis around the colony similar to the Streptococcus $\beta$-hemolytic colony. ${ }^{15}$

\section{Materials and methods}

In this study using laboratory tests. According to Woo et al., ${ }^{16}$ observations of the growth pattern of Staphylococcus aureus bacteria on blood agar using $\mathrm{O}, \mathrm{AB}$ and sheep blood essential compounds were observed macroscopically on colony morphology, number of colonies, and diameter of the hemolysis zone. Harris et al., ${ }^{17}$ stated the Research material: The sample used was a medium for blood base (Oxoid) which was added by $5 \%$ of human blood group $\mathrm{O}, \mathrm{AB}$, and sheep's blood. Using the Staphylococcus aureus (ATCC 25923) bacterial suspension which was equalized with Mc's standard solution. Farland 0.5 (150 million bacterial colonies) and depletion of $10-2 .{ }^{18}$

Data were obtained from macroscopic observations of colony morphology, counting the number of colonies, and measuring the diameter of the colony hemolysis zone that grew on blood agar using $\mathrm{O}, \mathrm{AB}$, and sheep blood essential human compounds and then incubated at $37^{\circ} \mathrm{C}$ for 24 and 48 hours. ${ }^{19}$ Blood collection in humans: Location: Vein media cubiti. Venous blood was taken as much as 10 $\mathrm{ml}$ and carried out defibrination..$^{20}$

Making blood agar media: Blood agar media composition: 40gram substrate Nutrient: as a source of energy/nutrition for bacteria; Sodium chloride (Merck) 5\% (v/ w): as a regulator of osmotic pressure equilibrium; 15\% order: as a media compactor. Procedure for making blood agar: Weigh 40 grams of Blood Agar Base (Oxoid). Subsequently added to $1000 \mathrm{ml}$ of distilled water, and sterilized by autoclaving for 15 minutes at $121^{\circ} \mathrm{C} .^{21}$
After leaving the autoclave, it is left until the temperature reaches $45^{\circ} \mathrm{C}-50^{\circ} \mathrm{C}$ or warm. Then add human blood group $\mathrm{O}, \mathrm{AB}$, and sterile sheep blood that has been defibrated as much as 7\% each. So on, pouring 9 Petri dishes in each amount of 9 Petri, as much as $15 \mathrm{ml}$. Dilution and implantation on experimental media: Bacterial inoculation was prepared by suspending Staphylococcus aureus (ATCC25923) into $\pm 1 \mathrm{ml} \mathrm{Pz}$. Then equal to Mc.Farland $0.5(0.5 \mathrm{ml}$ $\left.\mathrm{BaCl}_{2} 1,175 \%+99.5 \mathrm{ml} \mathrm{H} 2 \mathrm{SO} 41 \%\right)$. If it is too turbid, you can add sterile Pz and if it's too clear, you can add a bacterial suspension to the turbidity that is comparable to the standard turbidity of Mc. Farland 0.5 . The bacterial suspension is then made thinning 10-2 with sterile $\mathrm{Pz}$ as a thinner. Suspension 10-2 is planted as much as 1 standard use on 1 plate of media so that the blood of sheep as control and each plate of blood agar so that human blood groups $\mathrm{O}$ and $\mathrm{AB}$ by streak plate at 9 plates. Using the streak plate method (The principle of this method is to get a colony that is completely separate from the other colonies, thus facilitating the isolation process). Incubating for 24 and 48 hours at $37^{\circ} \mathrm{C}^{22}$ Then the morphology of the growing colony was observed. Count the number of bacterial colonies that grow by having the characteristics of Staphylococcus aureus and growing one by one. Measuring the diameter of the formed hemolysis zone. Next, the data were analyzed using the Kruskal Wallis Test.

\section{Results and discussion}

Observation of colony morphology, counting the number of colonies and measuring the diameter of the hemolysis zone formed in the blood agar media using essential $\mathrm{O}, \mathrm{AB}$, and sheep blood essential compounds. The results of observations on the growth of Staphylococcus aureus bacteria are colonized individually, small, round, smooth, white pigmented at 24-hour incubation period and of medium size and yellowish-white pigmented at 48 hours incubation period and colonies are counted. Surrounding the colony, there is a bright area which means that it is mememolisa. The hemolysis formed between the two is the same, namely $\beta$-hemolysis, as in the Table 1 below. (Figure 1).
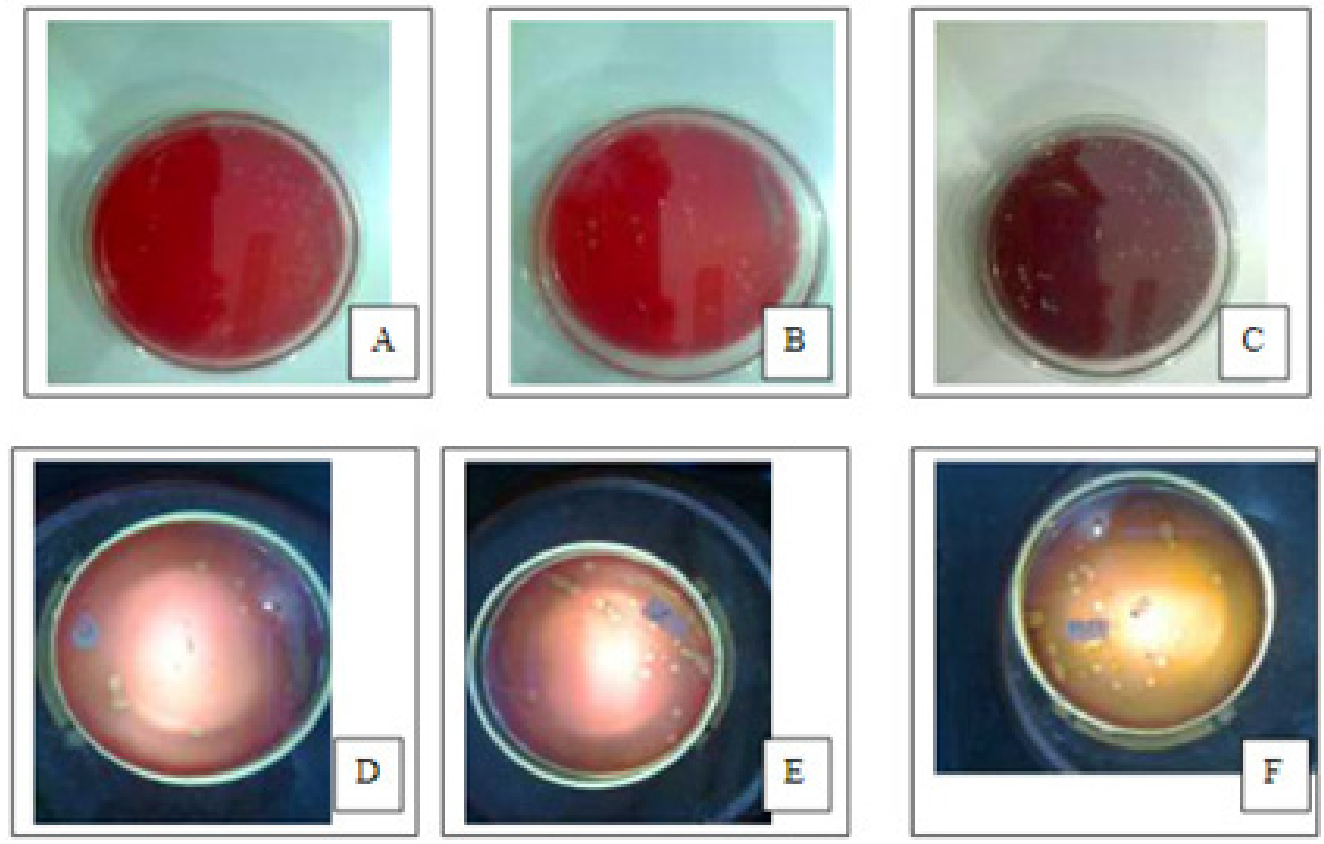

Figure I Growth of Staphylococcus aureus bacterial colonies. 
Table I Average result for the calculation of the number of colonies, colony morphology, and diameter of the hemolysis zone

\begin{tabular}{|c|c|c|c|c|c|}
\hline Essential compound & $\begin{array}{l}\text { Average } \\
\text { number of } \\
\text { colonies }\end{array}$ & $\begin{array}{l}\text { Morphological } \\
\text { average of colonies }\end{array}$ & $\begin{array}{l}\text { Average number of } \\
\text { colonies }\end{array}$ & $\begin{array}{l}\text { Morphological } \\
\text { average of } \\
\text { colonies }\end{array}$ & $\begin{array}{l}\text { Average Hemolysis } \\
\text { Zone Diameter }\end{array}$ \\
\hline 24 Hours & & & 48 Hours & & \\
\hline Human blood group $\bigcirc$ & 113 & Small convex white & 128 & $\begin{array}{l}\text { Yellowish white, } \\
\text { convex sized }\end{array}$ & 0,3 \\
\hline Human blood group $A B$ & 104 & Small convex white & 102 & $\begin{array}{l}\text { Yellowish white, } \\
\text { convex sized }\end{array}$ & 0,3 \\
\hline Sheep Blood & 122 & Small convex white & 133 & $\begin{array}{l}\text { Yellowish white, } \\
\text { convex sized }\end{array}$ & 0,3 \\
\hline
\end{tabular}

Note: $\mathrm{A}=$ Media for human blood type $\mathrm{O}$ with an incubation time of 24 hours. $\mathrm{B}=$ Media for human blood group $\mathrm{AB}$ with an incubation time of 24 hours. $\mathrm{C}=$ Sheep agar media with 24 -hour incubation time. $\mathrm{D}=$ media for human blood type $\mathrm{O}$ with 48 hours incubation time. $\mathrm{E}$ $=\mathrm{AB}$ blood type so that the blood group is 48 hours incubation. $\mathrm{F}=$ media for sheep blood agar with 48 hours incubation time.

From the Kruskal Wallis Test, the Asymp value is seen. Sig of 0.352 for the number of colonies and the diameter of the hemolysis zone which means is greater than $\alpha(0.05)$ so that Ho is accepted and $\mathrm{Hi}$ is rejected which means there is no significant difference between the growth patterns of Staphylococcus aureus bacteria in the Media so that the blood uses essential blood compounds in group $\mathrm{O}, \mathrm{AB}$, and sheep's blood. In general, there was no significant difference between the number of Staphylococcus aureus bacteria in the blood agar media using essential blood compounds of human groups $\mathrm{O}, \mathrm{AB}$, and sheep blood at the incubation times of 24 and 48 hours. This is because the type of blood used both contains carbohydrates which are the main source of nutrients to support bacterial growth.

Glucose is a type of carbohydrate that is most often used by microorganisms as an energy source. ${ }^{23}$ It's just an increase in the number of these bacteria that cannot be controlled properly. The majority of bacteria increased after 48 hours of incubation, but in some Petri dishes, this number decreased. Streak plate planting will get better results if the ose used is standard so that the bias is correlated between the number of bacteria to be planted and the number of bacteria that will grow. Or biased using a pouring system, so that bacterial growth can be evenly distributed throughout the surface of the media. From the observations, the formation of the hemolysis zone at 24-hour incubation is still incomplete and occurs in all Petri dishes. However, after 48 hours of incubation, the zone of hemolysis is completely formed, $\beta$-hemolysis and occurs on all plates.

From the measurement of the diameter of the hemolysis zone formed in the blood agar media using essential blood compounds of group $\mathrm{O}, \mathrm{AB}$, and sheep blood, the results obtained are not too far apart. This insignificant difference is due to morphological differences in human erythrocytes having a diameter of 6-8 $\mu \mathrm{m}$, far greater than erythrocyte sheep which are only $1-2.6 \mu \mathrm{m}$ in diameter.

From the growth pattern of Staphylococcus aureus bacteria which were observed based on the morphology of the colony, the number of colonies, and the diameter of the hemolysis zone in the media so that the blood using essential blood compounds of human groups $\mathrm{O}, \mathrm{AB}$, and sheep blood had almost the same results. The blood used should come from healthy humans and do not consume antibiotics so that the media can grow bacteria properly.
Different blood groups in making media so that blood does not have a major effect on bacterial growth. The difference is due to differences in monosaccharide molecules (simple carbohydrates) which are at the ends of oligosaccharides that are bound to proteins and glycolipids of red blood cell membranes (SDM). So that human blood groups $\mathrm{O}$ and $\mathrm{AB}$ can also be used as an alternative material for making blood media. ${ }^{24}$

\section{Conclusion}

Basedon the observations, it is known that there was no significant difference in the growth pattern of Staphylococcus aureus bacteria in the blood agar so that the blood compounds of $\mathrm{O}, \mathrm{AB}$, and sheep blood are essential. So that human blood groups $\mathrm{O}$ and $\mathrm{AB}$ can be used as an alternative material for making blood media.

\section{Acknowledgments}

None.

\section{Conflicts of interest}

The author declares there are no conflicts of interest.

\section{References}

1. Boyer M, Yutin N, Pagnier I, et al. Giant Marseillevirus highlights the role of amoebae as a melting pot in emergence of chimeric microorganisms. Proc Natl Acad Sci U S A. 2009;106(51):21848-21853.

2. Pugh DG, Baird AN. Sheep and Goat Medicine. 2012.

3. Tenover FC. Mechanisms of Antimicrobial Resistance in Bacteria. Am J Infect Control. 2006;34(5 Suppl 1):S3-10.

4. Montagne A, Barnes SR, Sweeney MD, et al. Blood-Brain barrier breakdown in the aging human hippocampus. Neuron. 2015;85(2):296-302.

5. Butler MT, Wang Q, Harshey RM. Cell density and mobility protect swarming bacteria against antibiotics. Proc Natl Acad Sci U S A. 2010;107(8):3776-3781.

6. Peleg AY, Hooper DC. Hospital-acquired infections due to gram-negative bacteria. N Engl J Med. 2010;362(19):1804-1813.

7. Textbook of Diagnostic Microbiology. 2001.

8. Lagier JC, Edouard S, Pagnier I, et al. Current and past strategies for bacterial culture in clinical microbiology. Clin Microbiol Rev. 2015;28(1):208236.

9. Ondusko DS, Nolt D. Staphylococcus aureus. Pediatrics in Review. 2018.

10. Kim SH, Lee HS, Ryu DS, et al. Antibacterial activity of silver-nanoparticles against Staphylococcus aureus and Escherichia coli. Korean Journal of Microbiology and Biotechnology. 2011. 
11. Valero A, Pérez Rodríguez F, Carrasco E, et al. Modelling the growth boundaries of Staphylococcus aureus: Effect of temperature, $\mathrm{pH}$ and water activity. Int J Food Microbiol. 2009;133(1-2):186-194.

12. Lu LC, Chen YW, Chou CC. Antibacterial activity of propolis against Staphylococcus aureus. Int J Food Microbiol. 2005;102(2):213-220.

13. Wiegand I, Hilpert K, Hancock REW. Agar and broth dilution methods to determine the minimal inhibitory concentration (MIC) of antimicrobial substances. Nat Protoc. 2008;3(2):163-175.

14. Acharya, Tankeshwar. Blood Agar: Composition, Preparation, Uses and Types of Hemolysis. 2013.

15. Buxton R. Blood Agar Plates and Hemolysis Protocols. American Society for Microbiology. 2005.

16. Woo KJ, Hye CK, Ki WK, et al. Antibacterial activity and mechanism of action of the silver ion in Staphylococcus aureus and Escherichia coli. Appl Environ Microbiol. 2008;74(7):2171-2178.

17. Harris LG, Foster SJ, Richards RG, et al. An introduction to Staphylococcus aureus, and techniques for identifying and quantifying S. aureus adhesins in relation to adhesion to biomaterials: Review. Eur Cell Mater. 2002;4:39-60.

18. Eloff JN. A sensitive and quick microplate method to determine the minimal inhibitory concentration of plant extracts for bacteria. Planta Med. 1998;64(8):711-713.
19. Cho KH, Park JE, Osaka T, et al. The study of antimicrobial activity and preservative effects of nanosilver ingredient. In Electrochimica Acta. 2005;51(5):956-960.

20. Guzman M, Dille J, Godet S. Synthesis and antibacterial activity of silver nano particles against gram-positive and gram-negative bacteria. Nanomedicine. 2012;8(1):37-45.

21. EUCAST. Media preparation for EUCAST disk diffusion testing and for determination of MIC values by the broth microdilution method A .Media for disk diffusion testing. European Committee on Antimicrobial Susceptibility Testing. 2017.

22. George WL, Sutter VL, Citron D, et al. Selective and differential medium for isolation of Clostridium difficile. J Clin Microbiol. 1979;9(2):214 219.

23. Chaudhuri SK, Lovley DR. Electricity generation by direct oxidation of glucose in mediator less microbial fuel cells. Nat Biotechnol. 2003;21(10):1229-1232.

24. Lynne AM, Haarmann D, Louden BC. Use of Blue Agar CAS Assay for Siderophore Detection. Journal of Microbiology \& Biology Education. $201 ; 12(1): 51-53$. 